\title{
Prevalence of Helicobacter pylori Infection Among School Children of 6 - 12 Years Age Group in Fayoum Governorate
}

\author{
Essam EIDin Gad EIRab Ahmed (1), Wael Sayed Mohammed ${ }^{(2)}$, Mohammed Mansour \\ Abbas ${ }^{(3)}$, Ahmed Mohammed Tawfik Huzein ${ }^{(4)}$. \\ (1) Professor of pediatrics - Faculty of medicine - Fayoum University. \\ (2) Lecturer of pediatrics - Faculty of medicine - Fayoum University. \\ (3) Lecturer of Clinical Pathology - Faculty of medicine - Fayoum University. \\ (4) M.B.B.CH - Pediatrics department - Faculty of Medicine - Fayoum University. \\ Corresponding author: Ahmed Mohammed Tawfik Huzien \\ E mail address: ahmed.tufy2012@gmail.com \\ Tel: 01068301515
}

\begin{abstract}
Background: Helicobacter pylori is a gram-negative bacterium colonizing human stomach and associated with numerous gastrointestinal diseases. Most of the people acquire $\mathrm{H}$. pylori infection during their early childhood.
\end{abstract}

Aim of the work: To evaluate the percentage of $\mathrm{H}$. pylori infection and its associated risk factors in school children of (6-12) years-age group in Fayoum Governorate.

Methods: This cross-sectional descriptive study was carried out at basic schools in Fayoum Governorate. A series of one hundred (100) apparently healthy children, living in Fayoum Governorate, attending basic schools in Fayoum city and village around it with their age ranging from (6-12) years included in the study and studied for the effect of age, sex and other risk factors which influencing the prevalence of H. pylori infection. Stool samples were obtained were assayed for $\mathrm{H}$. pylori Ag.
Results: Our study showed that the overall H. Pylori prevalence in cases of the study were 18\% (18/100) and frequency of positive cases didn't increase significantly with advances of age. In a trial to study risk factors for acquisition of $\mathrm{H}$. Pylori infection in our cases group, we found a highly significant difference between positive and negative cases regarding \{family crowding (number of family members and number of rooms \}, toilet sharing, gastrointestinal troubles, family history of gastric troubles and the centile value for weight and stature). Also, we found no significant differences between positive and negative cases regarding (Sex, age, residence, occupational and educational status of parents and cases who had owned or not pet animals).

Conclusion: The prevalence of $\mathrm{H}$. Pylori infection among children with their age raging from (6-12) years in Fayoum governorate (Egypt) was substantially close to developed countries. It could be one of the environmental causes of growth delay. 


\section{Introduction}

It is well known that H.pylori infection among children is associated with several extra gastric diseases, including growth reduction, iron-deficiency anemia, and idiopathic thrombocytopenic purpura (1). School children in developing countries are at-risk group due to several factors including low socioeconomic status, poor quality of drinking water, overcrowding, poor personal and environmental hygiene and food contamination (2). The diagnosis of H.pylori infection is generally based on methods described as invasive or non-invasive approaches. The invasive methods are based on endoscopy and biopsy using modalities like culture, histology and rapid urease test. Non-invasive diagnostic methods include urea breath test (UBT), fecal antigen testing, serology and more recently polymerase chain reaction testing of feces (3). Treatment is intended to eradicate H.pylori from the gastro-duodenal mucosa. It is vital to accomplish complete eradication as even a small residual colony will lead to re-colonization and reinfection (4).

\section{Subjects and Methods}

Study design: This study was a cross-sectional descriptive study.

Study population and sampling: A series of one hundred (100) apparently healthy children from 100 different families (48 males, 52 females), born and living in Fayoum Governorate, attending primary schools in Fayoum city and rural areas around it were included in the study.
Keywords: Helicobacter pylori, Helicobacter

pylori infections, School children.

\section{Inclusion Criteria:}

1. Age between 6 - 12 years.

2. Born and living in Fayoum Governorate.

3. Apparently Healthy children with no history of any chronic disease.

4. Not under specific treatment or had not been given antibiotics or antacids in the last two weeks and clinically free by general and local examination.

\section{Exclusion Criteria:}

1. Children received Antacid (Proton pump inhibitors (PPI) or $\mathrm{H} 2$ blocker) 15 days ago till the time of sampling.

2. Children received Antibiotics 15 days ago till the time of sampling.

3. Children with chronic diseases.

Children were selected in a random way from two schools, first one in Fayoum city (Al Barodya primary school) as an example for urban area and the other one in Abshway center (Senaru El Qiblyia El Gadida primary school) as an example for rural area in Fayoum Governorate.

\section{All cases were subjected to the following:}

1- A questionnaire was used to collect historical information on the following:

- Name, Age, Sex.

- Occupation and education level of the parents.

- Housing and living conditions: Residence, number of house rooms and household members, house pet animals and toilet sharing.

- History of GIT symptoms.

- Family history of GIT symptoms. 
2- Clinical examination: general examination including anthropometric measurements (standing height, weight) and local examination of all systems.

3- Investigation: all cases were tested for detection of

H. pylori Ag in stool.

\section{Results}

In this study cases were grouped according to their ages into two groups, a first group from (6 - 8 years) and a second group from (10 - 12 years) in order to identify the highest positive age group in relation to prevalence of $\mathrm{H}$. pylori infection. They were 48 males (48\%) and 52 females (52\%), with male to female ratio (1- 1.1) Figure (1).

The overall $\mathrm{H}$. pylori positive cases in children from (6 - 12 years) were $18 \%$ (18/100) compared to the overall $\mathrm{H}$. pylori negative cases were $82 \%(82 / 100)$ Figure (2).

The percentage of the positive cases was $14.6 \%(6 / 41)$ at the age of (6 - 8 years) and $65 \%$ $(12 / 59)$ at the age of (9 - 12 years). From the above observation it was realized that, there was no significant increase with H.pylori positive cases with advances of ages $(\mathrm{P}$-value $=0.465)$ Table $(\mathbf{1})$.

There is a highly significant difference between H.pylori positive and negative cases regarding family crowding (number of family members and number of rooms) P-value $<0.0001$, denoting that cases with higher family crowding had a higher prevalence of infection. As regards toilet sharing, there is highly significant difference between H.pylori positive and negative cases ( $\mathrm{P}$-value $<0.0001$ ). Also, there is no significant difference between families that residing urban and rural areas $(\mathrm{P}$-value $=0.638)$ Table
(2).There is no significant difference regarding educational status of parents $(\mathrm{P}$-value $=0.753)$ for father, $(\mathrm{P}$-value $=0.081)$ for mother between positive and negative cases Table (3). Also, There is no significant difference regarding occupational status of parents $(\mathrm{P}$-value $=0.455)$ for father, $(\mathrm{P}$-value $=0.496)$ for mother between positive and negative cases Table (4).

It was realized that a significant difference was found in the prevalence of $\mathrm{H}$. pylori in relation to history GIT symptoms among studied group (p-value $=0.003$ ) Figure (3). Also, a significant difference was found in the prevalence of H.pylori in relation to family history of GIT symptoms (P-value =0.029) Figure (4).

For statistical purposes, cases were divided according to their centile value for weight and length into two groups (< 25th, $>25$ th) centile (Francesco perri et al., 2001). The difference was highly significant, H. pylori infected cases tended to have higher percentage below the 25th centile for weight than percentage above the 25th centile. Also, H. pylori infected cases tended to have higher percentage below the 25th centile for length than percentage above the 25th centile Figure (5). 


\section{Discussion}

Helicobacter pylori infection is a global public health problem, affecting more than half of the world's population. The infection is thought to occur early during childhood but can remain asymptomatic, with long-term clinical squalae including chronic gastritis, gastric cancer, peptic ulcer disease (Plummer et al., 2015).

In our study, the overall prevalence was $18 \%$ $(18 / 100)$. It was close to it was quite close to the results in developed countries as it was been found that prevalence in United States were 12.1\% (Chongsk et al., 2003) and in Sweden the prevalence rate was 13.6 $\%$ (Granstrom et al., 2002). In contrast, the prevalence rate of $\mathrm{H}$. pylori infection was much higher in developing countries like other governorate in Egypt. It was $51 \%$ in Menoufia (El Shafie et al., 2004), In Alexandria, the results revealed H.pylori prevalence of $27.1 \%$ among school children (Abdel-Ghany $M$ et al., 2003).

This was in agreement with the study which showed that, the prevalence of infection don't increase with age among children (Mahmud et al., 2015), However our results contradict with the result which showed that, the prevalence of infection steadily increases with age among children (Balci et al., 2011).

In our study we found a highly significant difference between positive and negative cases regarding family crowding ( $\mathrm{p}$-value <0.0001), denoting that cases with higher family crowding and sharing toilet with other families regardless of residence had a higher prevalence of infection. These results agree with (Queiroz et al., 2013) and contradict with (Zhou et al., 2018).
There was no significance as regarding relation between $H$. pylori infection and educational and occupational status of parents. These results agreed with (Hestvik et al., 2010; Zhou et al., 2018) and contradicted with (El Shafie et al., 2004).

In our study we found that there was a significant difference in the prevalence of H.pylori infection in relation to history of gastrointestinal troubles among studied group $(\mathrm{P}$-value $=0.003)$. This agreed with (Telmesani A.M, 2009) and contradicted with (Mansour MMHK et al., 2012).

By considering the centile value for stature, a highly significant difference in height was found between infected and non-infected children in those cases (P- value $<0.0001)$. This agreed with (El Shafie et al., 2004) and contradicted with (Cherian et al., 2009).

\section{Conclusion}

The prevalence of H. Pylori infection among children with their age raging from (6-12) years in Fayoum governorate (Egypt) was substantially close to developed countries. H. pylori infection could be one of the environmental causes of growth delay. Also, it could be one of the causes of gastrointestinal troubles specially recurrent abdominal pain and dyspepsia among school aged children. 


\section{References}

[1] Abdel Ghany M. El-massry, Tarek M. Thabett, Aly N. Kassemt, Salah El-din, and A. Badr. N.D. (2003): "Helicobacter Pylori Infection among School Children in Alexandria: Possible Association with Intestinal Parasitic Infections." Bulletin of High Institute of Public Health, vol.33 No.1.

[2] Balci YI, Aral YZ, Covut IE, Polat Y, Turk M and Acimis $\mathbf{N}$ (2011): The frequency of Helicobacter Pylori infection in Beta Thalassemia major Patients with recurrent abdominal pain. Pak J Med Sci; 27(2):316-319.

[3] Chong SK and Zollinger TW. (2003): The seroprevalence of Helicobacter pylori in a referral population of children in United States. $\mathrm{M} j$ Gastroenterol, 98: 2162.

[4] El Shafie AM, Kandel SH, Bahbah MH. (2004): Seroprevalence of Helicobacter .pylori infection among infants and children of Menoufia governorate Bahbah WA, Msc thesis.

[5] F.-C. Kuo, C.-Y. Wu, C.-H. Kuo. (2014): "The utilization of a new immunochromatographic test in detection of Helicobacter pylori antibody from maternal and umbilical cord serum," BioMed Research International, vol. 2014, Article ID 568410.

[6] Francesco Perri, Maria, Rocco, vito Annese. (2001): H. pylori infection and growth delay in older children. Arch Dis child; 77: 46-49.

[7] Gold BD, Colletti RB, Abbott M. (2000): Helicobacter pylori Infection in Children: Recommendations for Diagnosis and Treatment. Journal of Pediatric Gastroenterology and Nutrition 31:490-497 ONovember Lippincott Williams \& Wilkins, Inc., Philadelphia.
[8] Granstrom M, Tindbery Y,B lennow M. (2002): Seroepidemiology of $\mathrm{H}$. pylori infection in a Cohort of children monitored from 6 month to 11 years of age. J Clin. Microbiol; 35 (2): 468. 70.

[9] Hestvik E, Tylleskar, Kaddu-Mulindwa DH, Ndeezil G. (2010): Helicobacter pylori in apparently healthy children aged 0-12 years in urban Kampala, Uganda; accommunity-based cross ectional survey BMC Gastroenterol; 19; 62.

[10] Mahmud S, Shah SA and Ali S. (2015): Frequency of Helicobacter pylori (HP) infection in children with recurrent abdominal pain (RAP). Pak Armed Forces Med J; 65: 358.

[11] Mansour, M. M. H. K., Al Hadidi Kh, M., Omar, M. A. (2012): Helicobacter pylori and recurrent abdominal pain in children: Is there any relation?. Tropical Gastroenterology, 33(1), 55-61.

[12] Megraud F. (2005): European Pediatric Task Force on Helicobacter pylori. Comparison of noninvasive tests to detect Helicobacter pylori infection in children and adolescents: results of a multicenter European study. J Pediatr.146 (2):198-203.

[13] Plummer M., Franceschi S., Vignat J., Forman D., de Martel C. (2015): Global burden of gastric cancer attributable to Helicobacterpylori. International Journal of Cancer. 136(2):487-490.

[14] Queiroz DM,Saito M,Rocha AM. (2013): H.pylori infection in infant and toddlers in south America: concordance between (13c) urea breath test and monoclonal H.pylori stool antigen test.51:37353740 . 
[15] R. Darko, A. E. Yawson, V. Osei, J. OwusuAnsah, and S. Aluze-Ele. (2015): "Changing patterns of the prevalence of Helicobacter pylori among patients at a corporate hospital in Ghana," Ghana Medical Journal, vol. 49, no. 3, pp. 147-153.

[16] Telmesani A. M. (2009): Helicobacter pylori: prevalence and relationship with abdominal pain in school children in Makkah City, western Saudi Arabia. Saudi journal of gastroenterology: official journal of the Saudi Gastroenterology Association, 15(2), 100-103.

[17] Zhou, Ying, Ziqing Ye, Jie Huang, and Ying Huang. (2018): "High Prevalence and Low Spontaneous Eradication Rate of Helicobacter Pylori Infection among Schoolchildren Aged 7 - 12 Years," 15. 
Table (1): Relation between age and H.pylori infection among studied group.

\begin{tabular}{||c|c|c|c|c|c|c||}
\hline \multirow{2}{*}{ Age } & \multicolumn{2}{|c|}{$\begin{array}{c}\text { Positive } \\
(\mathbf{N = 1 8})\end{array}$} & \multicolumn{2}{c|}{$\begin{array}{c}\text { Negative } \\
\text { (N=82) }\end{array}$} & \multirow{2}{*}{ Total } & \multirow{2}{*}{ P-value $^{\#}$} \\
\cline { 2 - 6 } & $\mathbf{N}$ & $\%$ & $\mathbf{N}$ & $\%$ & & \\
\hline 6-8 years & 6 & $14.6 \%$ & 35 & $85.4 \%$ & 41 & \multirow{2}{*}{0.465 (NS) } \\
\hline 9-12 years & 12 & $20.3 \%$ & 47 & $79.7 \%$ & 59 & \\
\hline
\end{tabular}

Table (2): Relation between demographic data and H.pylori infection among studied group.

\begin{tabular}{|c|c|c|c|c|c|}
\hline & \multicolumn{2}{|c|}{$\begin{array}{c}\text { Positive } \\
(\mathrm{N}=18)\end{array}$} & \multicolumn{2}{|c|}{$\begin{array}{c}\text { Negative } \\
(\mathrm{N}=82)\end{array}$} & \multirow[t]{2}{*}{ P-value } \\
\hline & $\mathbf{N}$ & $\%$ & $\mathbf{N}$ & $\%$ & \\
\hline \multicolumn{6}{|c|}{ Room's number } \\
\hline$\leq 2$ & 14 & $60.9 \%$ & 9 & $39.1 \%$ & \multirow{2}{*}{$\begin{array}{c}<0.0001 \\
\text { (S) }\end{array}$} \\
\hline$>2$ & 4 & $5.2 \%$ & 73 & $94.8 \%$ & \\
\hline \multicolumn{6}{|c|}{ Family members } \\
\hline$>5$ & 15 & $60.0 \%$ & 10 & $40.0 \%$ & \multirow{2}{*}{$\begin{array}{c}<0.0001 \\
(\mathrm{~S})\end{array}$} \\
\hline$\leq 5$ & 3 & $4.0 \%$ & 72 & $96.0 \%$ & \\
\hline \multicolumn{6}{|l|}{ Toilet sharing } \\
\hline Yes & 13 & $61.90 \%$ & 8 & $38.10 \%$ & \multirow{2}{*}{$\begin{array}{c}<0.0001 \\
(S)\end{array}$} \\
\hline No & 5 & $6.30 \%$ & 74 & $93.70 \%$ & \\
\hline \multicolumn{6}{|l|}{ Residence } \\
\hline Rural & 9 & $16.4 \%$ & 46 & $83.6 \%$ & \multirow{2}{*}{$0.638(\mathrm{NS})$} \\
\hline Urban & 9 & $20.0 \%$ & 36 & $80.0 \%$ & \\
\hline
\end{tabular}

Table (3): Relation between educational level of parents and H.pylori infection among studied group.

\begin{tabular}{|c|c|c|c|c|c|}
\hline \multirow[t]{2}{*}{ Education level } & \multicolumn{2}{|c|}{$\begin{array}{c}\text { Positive } \\
(\mathrm{N}=18)\end{array}$} & \multicolumn{2}{|c|}{$\begin{array}{c}\text { Negative } \\
(\mathrm{N}=82)\end{array}$} & \multirow{2}{*}{ P-value ${ }^{\#}$} \\
\hline & $\mathbf{N}$ & $\%$ & $\mathbf{N}$ & $\%$ & \\
\hline \multicolumn{6}{|l|}{ Father's education } \\
\hline Illiterate & 2 & $18.2 \%$ & 9 & $81.8 \%$ & \multirow{4}{*}{$0.753(\mathrm{NS})$} \\
\hline Basic & 7 & $24.1 \%$ & 22 & $75.9 \%$ & \\
\hline Secondary & 8 & $14.5 \%$ & 47 & $85.5 \%$ & \\
\hline High & 1 & $20.0 \%$ & 4 & $80.0 \%$ & \\
\hline \multicolumn{6}{|l|}{ Mother's Education } \\
\hline Illiterate & 7 & $28.0 \%$ & 18 & $72.0 \%$ & \multirow{3}{*}{$0.081(\mathrm{NS})$} \\
\hline Basic & 4 & $30.8 \%$ & 9 & $69.2 \%$ & \\
\hline Secondary & 7 & $11.3 \%$ & 55 & $88.7 \%$ & \\
\hline
\end{tabular}


Table (4): Relation between occupation of parents and H.pylori infection among studied group.

\begin{tabular}{|c|c|c|c|c|c|}
\hline \multirow{2}{*}{ Occupation } & \multicolumn{2}{|c|}{$\begin{array}{c}\text { Positive } \\
(\mathrm{N}=18)\end{array}$} & \multicolumn{2}{|c|}{$\begin{array}{c}\text { Negative } \\
(\mathrm{N}=82)\end{array}$} & \multirow{2}{*}{ P-value ${ }^{\#}$} \\
\hline & $\mathbf{N}$ & $\%$ & $\mathbf{N}$ & $\%$ & \\
\hline \multicolumn{6}{|c|}{ Father's occupation } \\
\hline Blue & 17 & $19.8 \%$ & 69 & $80.2 \%$ & \multirow{2}{*}{$0.455(\mathrm{NS})$} \\
\hline White & 1 & $7.1 \%$ & 13 & $92.9 \%$ & \\
\hline \multicolumn{6}{|c|}{ Mother's occupation } \\
\hline Not & 18 & $19.1 \%$ & 76 & $80.9 \%$ & \multirow{3}{*}{$0.496(\mathrm{NS}$} \\
\hline Blue & 0 & $0.0 \%$ & 2 & $100.0 \%$ & \\
\hline White & 0 & $0.0 \%$ & 4 & $100.0 \%$ & \\
\hline
\end{tabular}

Figure (1): Age and sex distribution of the studied group.

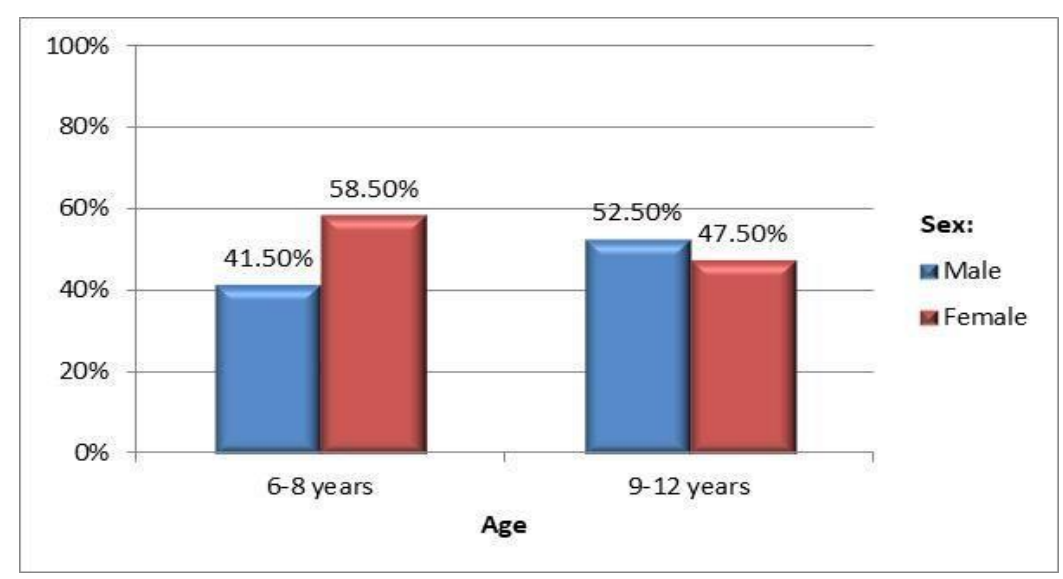

Figure (2): prevalence of H.pylori infection among studied group.

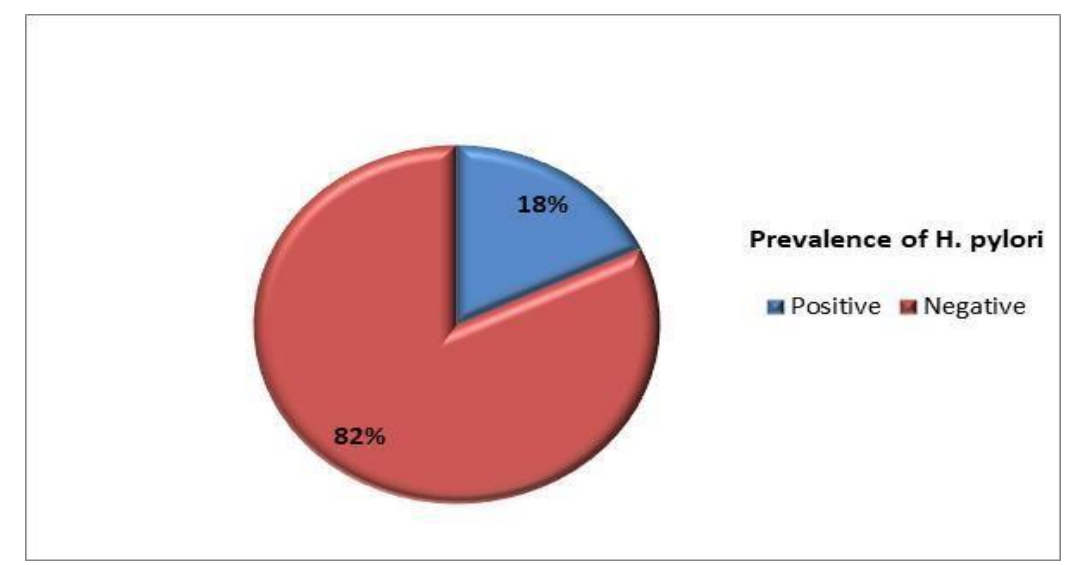


Figure (3): Relation between history of GIT symptoms and H.pylori infection among studied group.

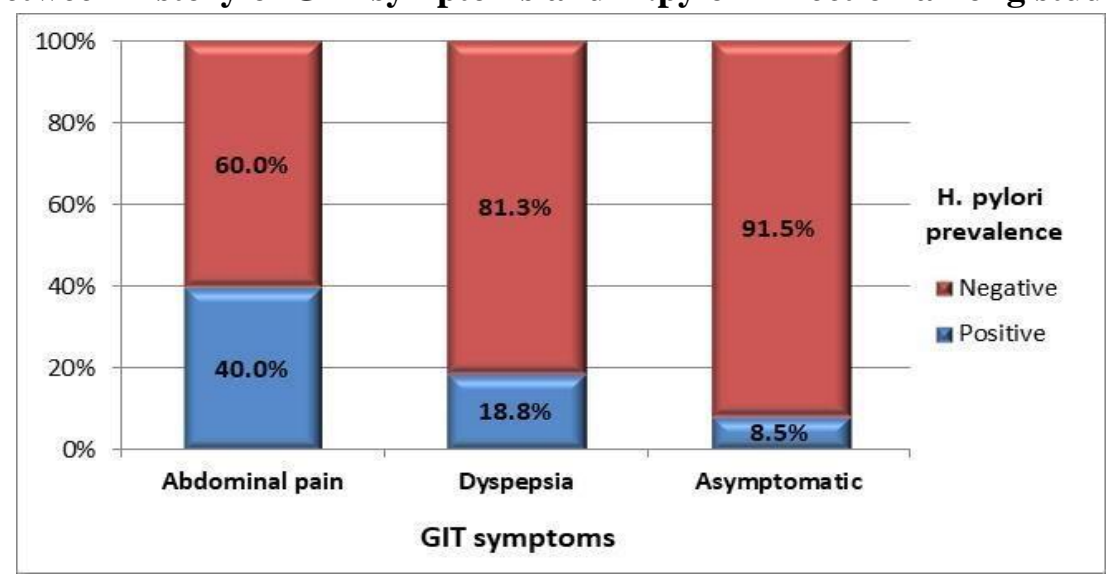

Figure (4):Relation between family history GIT symptoms and H.pylori infection.

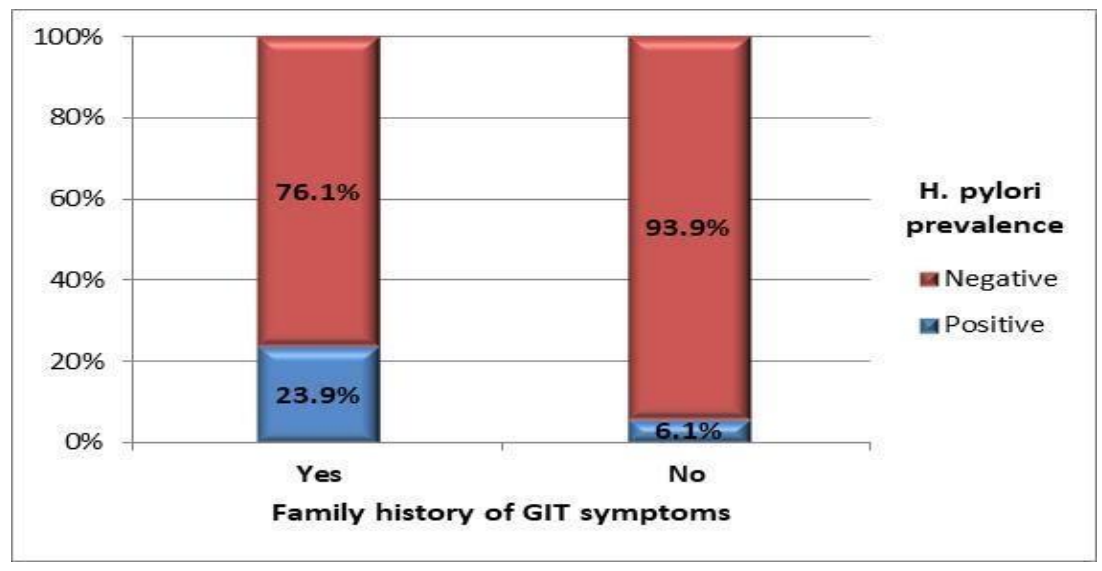


Figure (5): Effect of H.pylori infection on weight and length centile.

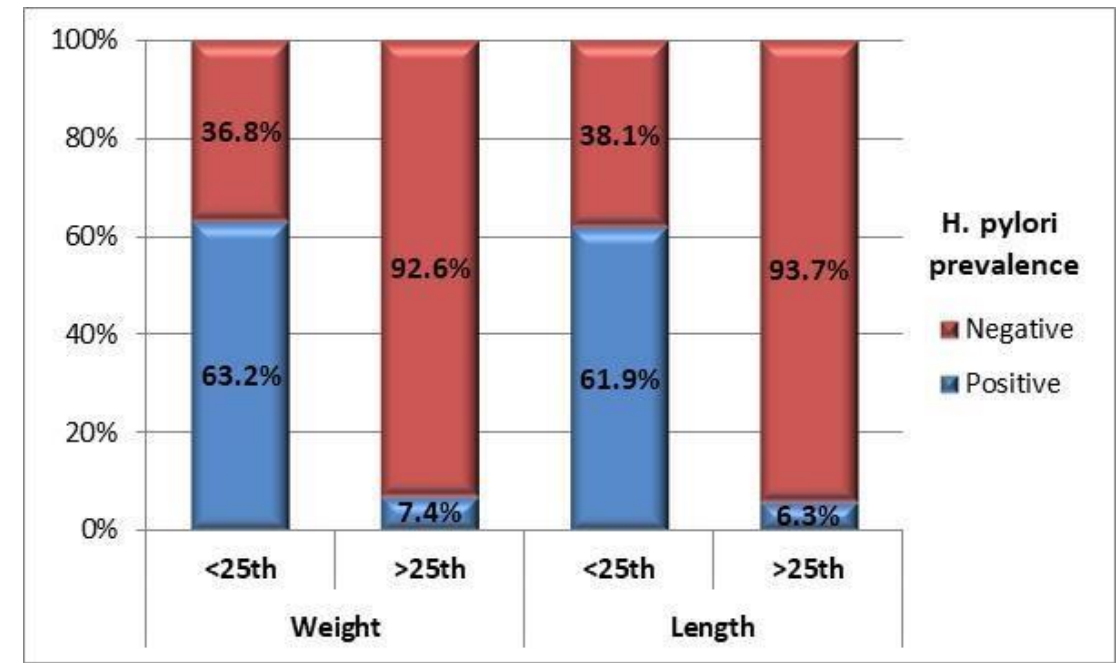

